\title{
POLLUTION ASSESSMENT AND SOURCE APPROXIMATION OF TRACE ELEMENTS IN THE FARMLAND SOIL NEAR THE TRAFFICWAY
}

\author{
Linhua SUN ${ }^{*}$ \\ School of Resources and Civil Engineering, Suzhou University, 234000, Anhui, China; Key Laboratory of Mine \\ Water Resource Utilization of Anhui Higher Education Institute, Suzhou University, 234000, Anhui, China
}

Received 10 June 2019; accepted 18 August 2019

\begin{abstract}
The traffic related environmental pollution problems have attracted a lot of attention. In this study, contents of eight trace elements along with $\mathrm{Fe}$ and $\mathrm{Mn}$ in the farmland soil near a trafficway of Suzhou, Anhui province, China have been measured for the pollution assessment and source identification (along with quantification). The results show that iron is the most abundant element, followed by manganese, zinc, chromium, nickel, copper, lead, arsenic, cobalt and cadmium. They have coefficients of variation range between 0.028 and 0.281 , indicating that some of them might have multi-sources. The pollution indexes (including single pollution, geo-accumulation and the Nemerow composite indexes) indicate that the soil samples are slightly polluted. Multivariate statistical analyses (including correlation, cluster and factor analyses) have identified three sources (geogenic, traffic and agriculture related) responsible for the elemental concentrations in the soils. Moreover, the EPA Unmix model have calculated their mean contributions to be $33.4 \%, 33.2 \%$ and $33.3 \%$, respectively.
\end{abstract}

Keywords: soil pollution, trace elements, source approximation, traffic, agriculture.

\section{Introduction}

With the rapid development of China's economy, the transportation industry is becoming more and more important. Under this situation, China's road construction has undergone rapid development during the past decades. "Statistical Bulletin on Transportation Industry Development in 2017, China" reported that China's total trafficway mileage has reached 4.77 million kilometres at the end of 2017 (Ministry of Transport of the People's Republic of China [MOT], 2017).

Along with this situation, a series of environmental problems (e.g. noise, vibration, emission of gas, water, residue and waste) related to traffic have been produced and attracted a lot of attention. And therefore, a large number of studies have been carried out for these environmental problems and most of them focused on the noise and air pollution (Carslaw, 2005; Zechmeister, Hohenwallner, Riss, \& Hanus-Illnar, 2005; Mehdi, Kim, Seong, \& Arsalan, 2011; De Silva, Ball, Huynh, \& Reichman, 2016).

Among these studies, the soil pollution related to the traffic is important for the agriculture areas, because the vehicle exhaust emissions have become an important factor for the increasing of trace elements such as $\mathrm{Co}, \mathrm{Pb}, \mathrm{Cu}$,
$\mathrm{Zn}$ and $\mathrm{Cd}$ in the atmosphere (Harrison, Tilling, Romero, Harrad, \& Jarvis, 2003; Alsbou \& Al-Khashman, 2018), and which can increase the trace elemental concentrations in soil on both sides of trafficway (mostly, the $\mathrm{Zn}$, $\mathrm{Co}, \mathrm{Pb}, \mathrm{Cu}, \mathrm{Cd}$ and $\mathrm{Mn}$ ) (Chon, K. W. Kim, \& J. Y. Kim, 1995; Chen, J. W. C. Wong, Zhou, \& M. H. Wong, 1997; Zupančič, 1999; Linde, Bengtsson, \& Öborn, 2001; Guo et al., 2007). Moreover, because most of the trafficways are located crossing the farmland, and the crops grown in these polluted soils will be affected by pollution (Antisari, Orsini, Marchetti, Vianello, \& Gianquinto, 2015), which will then influence the human health through food chain (Sun, Zhu, \& Zhou, 2018).

Due to their harmful effects for human beings, some of the trace elements, especially the toxic ones (e.g. Hg, $\mathrm{Cd}, \mathrm{Pb}, \mathrm{Zn}$ et al.) (Duruibe, Ogwuegbu, \& Egwurugwu, 2007), have long been concerned by scientists, and a large number of studies related to their toxicological characteristics (Ji, Cao, \& Li, 2015; Arojojoye, Oyagbemi, \& Afolabi, 2018), concentrations, distribution and forms in the environments (M. S. Islam, Ahmed, Raknuzzaman, Habibullah-Al-Mamun, \& M. K. Islam, 2015; Tóth, Hermann, Da Silva, \& Montanarella, 2016), sources (Huang et al., 2015), migration, enrichment and transformation

*Corresponding author. E-mail: sunlinh@126.com 
(R. Li, Zhao, Y. Li, Wang, \& Zhu, 2015) have long been carried out.

The quality of soil is important for Suzhou because agriculture is one of the major industries for the city. And therefore, a series of studies related to the soil environment have been carried out (Sun, Xie, \& Guo, 2014; Sun \& Feng, 2019). However, there is no report about the traffic related soil environment. In this study, a total of seventy-five surface soil samples have been collected from the farmland near a representative trafficway (with high density of traffic) in the Suzhou city, Anhui province, China, and the concentrations of eight trace elements (As, $\mathrm{Cd}, \mathrm{Co}, \mathrm{Cr}, \mathrm{Cu}, \mathrm{Ni}, \mathrm{Pb}$ and $\mathrm{Zn}$ ) along with $\mathrm{Fe}$ and $\mathrm{Mn}$ have been measured and analysed by statistical methods, the goals of the study include: (1) pollution assessment of the soils by these elements and (2) identification and quantification of the different sources responsible for their concentrations.

\section{Materials and methods}

\subsection{Study site}

Suzhou is located in the northern Anhui province, China, with longitude between $116^{\circ} 09^{\prime}$ and $118^{\circ} 10^{\prime}$ and latitude between $33^{\circ} 18^{\prime}$ and $34^{\circ} 38^{\prime}$. The annual rainfall is 774-895 mm with mean temperature $15.7^{\circ} \mathrm{C}$ (Semi-humid monsoon climate in warm temperate zone). The city has been called as the China's granary and energy base because agriculture and coal related industries are the most import industries in the city. The main crops in the area include wheat, corn, soybean, cotton, potato, rapeseed, peanuts and fruit etc. And therefore, the quality of soil is important for the development of the area.

During the past ten years, the economy of Suzhou has undergone rapid development, especially the development of transportation because of its important geographical location, including the railways and trafficways. In relation to this high speed of development, there are many kinds of environmental problems have been resulted in: e.g. the air pollution, water pollution and soil pollution, and a series of studies have been processed (Mei, Li, Sun, Gui, \& Wang, 2011; Sun, Liu, \& Cheng, 2016a).

The Suzhou Avenue is an urban express connecting the urban area and the high railway east station of Suzhou (Figure 1). It's an eight-lane road with two non-motorized lanes, the width is 40 meters, and the average traffic volume is near 10.000 vehicles per day and a peak period of nearly 1.500 vehicles per hour.

\subsection{Sampling and analysis}

Seventy-five surface soil samples $(<10 \mathrm{~cm}$ depth) in the farmland near the trafficway have been collected in March 2019, and the detailed sample distributions are shown in Figure 1: there are 15 samples collected near the southern edge of the trafficway (within $1 \mathrm{~m}$ from the roadside) in a line with distance near $150 \mathrm{~m}$ between the near two samples, and then the samples (15 samples in each line) in another 4 lines parallel to the first line have been collected. The lines between each other are $10 \mathrm{~m}$.

All of the soil samples have been firstly air-dried in room temperature, and then the debris (animals and plants) have been manually removed. After these procedures, all of the samples were parched for $24 \mathrm{~h}$ with $80^{\circ} \mathrm{C}$ in the dryer and then powdered to be small than 200 meshes $(<0.075 \mathrm{~mm})$. Finally, all of the samples (powder) have been compressed to be tablets under the pressure of $30 \mathrm{t}$.

The concentrations of the elements (including the As, $\mathrm{Cd}, \mathrm{Co}, \mathrm{Cr}, \mathrm{Cu}, \mathrm{Fe}, \mathrm{Mn}, \mathrm{Ni}, \mathrm{Pb}$ and $\mathrm{Zn}$ ) have been analysed by the X-ray fluorescence spectrometer (Innov-X Explorer 9000 SDD, USA) along with the National standard sediment sample of China (GSS-16) for calibration in the Key Laboratory of Mine Water Resource Utilization of Anhui Higher Education Institute, Suzhou University, Anhui province, China. Previous studies indicated that the portable XRF instrument gave excellent correlation with the laboratory-based reference AAS method (Radu \& Diamond, 2009). The relative standard derivation (RSD) is less than $10 \%$ except for $\mathrm{Cd}(30 \%)$, which was quantified by the comparison of the measured and standard concentrations of GSS-16 with the following equation:

$$
\operatorname{RSD}=\left(\mathrm{S}_{\mathrm{M}}-\mathrm{S}_{\mathrm{S}}\right) / \mathrm{S}_{\mathrm{S}}
$$

After the analyses, the concentrations of elements have been recalculated by:

$$
\mathrm{C}_{\mathrm{M}}=\mathrm{C}_{\mathrm{T}} \times\left(\mathrm{S}_{\mathrm{S}} / \mathrm{S}_{\mathrm{M}}\right),
$$

where $C_{M}$ is the concentration of samples, $C_{T}$ is the concentration of samples reported by the instrument, $\mathrm{S}_{\mathrm{S}}$ and

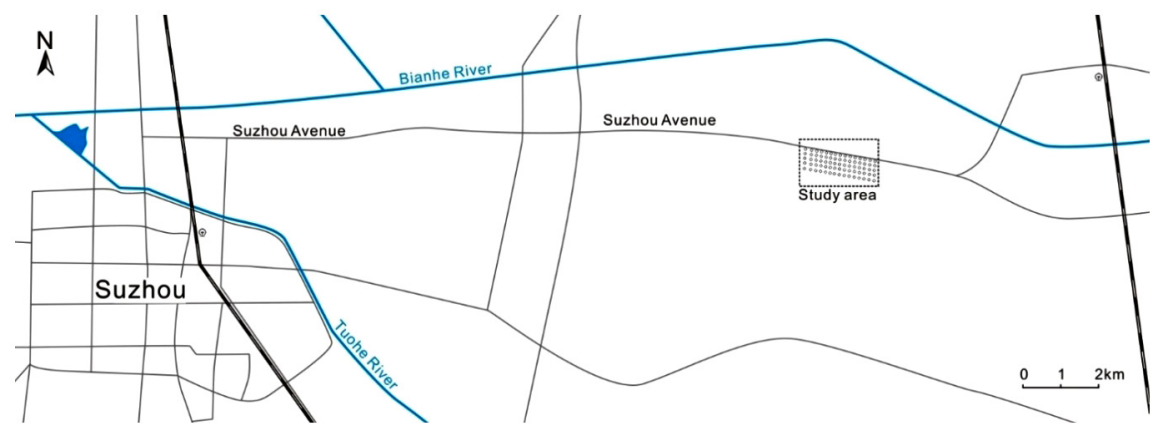

Figure 1. Location of the study area and sample distributions. Circles are the samples 
$\mathrm{S}_{\mathrm{M}}$ are the standard and mean measured concentrations of the standard samples (GSS-16), respectively.

\subsection{Data treatment procedures}

All of the data were firstly processed for basic statistical analyses by the Mystat 12 software, and the minimum, maximum, mean, standard deviation, coefficient of variation and the p-value of the normal distribution test have been obtained.

Then, a series of methods, including the single pollution index $\left(\mathrm{P}_{\mathrm{i}}\right)$ (J. Liang, Chen, Song, Han, \& Z. Liang, 2011), the geo-accumulation index $\left(\mathrm{I}_{\text {geo }}\right)$ (Praveena, Ahmed, Radojevic, Abdullah, \& Aris, 2008) and the Nemerow composite index $\left(\mathrm{P}_{\mathrm{s}}\right)$ (Dai, Li, Zhang, Wang, \& Yu, 2008) have been chosen for the quality evaluation of the samples. The detailed information for the calculations can be found in the following text.

Finally, correlation, cluster and factor analyses have been applied for getting the qualitative information about the sources of elements. Additionally, the Unmix model created by the US Environmental Protection Agency (EPA) was conducted for getting the quantitative information about the sources, which have long been used for environmental studies (Lewis, Norris, Conner, \& Henry, 2003; Han, Cao, \& Posmentier, 2006; Lang \& Yang, 2014; Sun, Peng, \& Cheng, 2016b).

The Unmix model is a receptor-oriented model for quantitative analysis of pollutant sources or chemical species. The source types are identified by comparing them to measured profiles, whereas the source contributions are used to determine how much each source contributed to a sample. The basic idea of the model is:

$$
\mathrm{C}_{\mathrm{M}}=\sum \mathrm{X}_{1} \times \mathrm{S}_{1}+\mathrm{X}_{2} \times \mathrm{S}_{2} \ldots \mathrm{X}_{\mathrm{n}} \times \mathrm{S}_{\mathrm{n}}
$$

where $C_{M}$ is the measured concentration of sample, $S_{n}$ is the profile contributed by any types of sources, $X_{n}$ is the portion of $\mathrm{S}_{\mathrm{n}}$, and $\left(\mathrm{X}_{\mathrm{n}} \times \mathrm{S}_{\mathrm{n}}\right) / \Sigma\left(\mathrm{X}_{\mathrm{n}} \times \mathrm{S}_{\mathrm{n}}\right)$ is the contribution of source $n$ for the $C_{M}$.

\section{Results and discussion}

\subsection{Concentrations of trace elements}

The analytical results of trace elemental concentrations are shown in Table 1. It can be concluded from the table that the elements in this study have the following decreasing order: $\mathrm{Fe}>\mathrm{Mn}>\mathrm{Zn}>\mathrm{Cr}>\mathrm{Ni}>\mathrm{Cu}>\mathrm{Pb}>\mathrm{As}>\mathrm{Co}>\mathrm{Cd}$, and their mean concentrations are $30026,433,52.6,52.4$, $31.5,30.0,27.3,11.4,11.1$ and $0.089 \mathrm{mg} / \mathrm{kg}$, respectively.

As suggested by previous studies, the coefficient of variation $(\mathrm{CV})$ can be used for identifying the types of pollution distribution: a high CV (>0.90) means high extent of spatial variation and indicating high degree of anthropogenic contribution or multi-sources, whereas a low CV $(<0.10)$ means low extent of spatial variation and indicating low degree of anthropogenic contribution or single source (Sarkar, Datta, \& Hannigan, 2011). In this study, the $\mathrm{Fe}, \mathrm{Pb}$ and $\mathrm{Zn}$ have low CVs $(<0.10)$, which means that concentrations of these elements vary slightly from area to area and indicating that they have relatively simple and homogeneous sources. Other elements except for $\mathrm{Fe}, \mathrm{Pb}$ and $\mathrm{Zn}$ have medium CVs (0.102-0.281), which indicates that they have moderate degrees of spatial variability, and indirectly suggesting the multi-source of them.

Moreover, the test of normality distribution can also give information about the distribution of the elemental concentrations, because a normal distribution of the elemental concentration is always considered to represent single source. In this study, most of the elements except for $\mathrm{Co}, \mathrm{Mn}$ and $\mathrm{Cu}$ have $\mathrm{p}$-values $>0.05$, indicating that they can pass the normal distribution test ( $p$-value $>0.05$ ),

Table 1. Descriptive statistics of heavy metal concentrations $(\mathrm{mg} / \mathrm{kg})$ in the soil samples

\begin{tabular}{|l|c|c|c|c|c|c|c|c|c|c|}
\hline \multicolumn{1}{|c|}{ Species } & $\mathrm{As}$ & $\mathrm{Cd}$ & $\mathrm{Co}$ & $\mathrm{Cr}$ & $\mathrm{Cu}$ & $\mathrm{Fe}$ & $\mathrm{Mn}$ & $\mathrm{Ni}$ & $\mathrm{Pb}$ & $\mathrm{Zn}$ \\
\hline $\mathrm{N}$ of Cases & 75 & 75 & 75 & 75 & 75 & 75 & 75 & 75 & 75 & 75 \\
\hline Minimum & 8.18 & 0.036 & 7.67 & 37.2 & 18.2 & 24,993 & 322.047 & 15.7 & 25.5 & 42.1 \\
\hline Maximum & 16.6 & 0.148 & 12.8 & 63.6 & 46.6 & 33,762 & 604.044 & 45.0 & 28.8 & 61.5 \\
\hline Mean & 11.4 & 0.089 & 11.1 & 52.4 & 30.0 & 30,026 & 433 & 31.5 & 27.3 & 52.6 \\
\hline $\begin{array}{l}\text { Standard } \\
\text { Deviation }\end{array}$ & 1.93 & 0.025 & 1.31 & 5.32 & 6.54 & 2,070 & 58.5 & 5.89 & 0.758 & 4.24 \\
\hline $\begin{array}{l}\text { Coefficient of } \\
\text { Variation }\end{array}$ & 0.169 & 0.281 & 0.118 & 0.102 & 0.218 & 0.069 & 0.135 & 0.187 & 0.028 & 0.081 \\
\hline p-value & $>0.15$ & $>0.15$ & $<0.01$ & $>0.15$ & $<0.01$ & $>0.15$ & 0.025 & $>0.15$ & $>0.15$ & $>0.15$ \\
\hline Mean $\mathrm{P}_{\mathrm{i}}$ & 1.02 & 0.92 & 0.87 & 0.86 & 1.33 & 1.02 & 0.74 & 1.17 & 1.05 & 0.71 \\
\hline Highest $\mathrm{P}_{\mathrm{i}}$ & 1.48 & 1.53 & 1.01 & 1.04 & 2.06 & 1.15 & 1.04 & 1.67 & 1.11 & 0.83 \\
\hline $\mathrm{I}_{\text {geo }}$ & -0.56 & -0.71 & -0.78 & -0.80 & -0.18 & -0.55 & -1.01 & -0.36 & -0.51 & -1.08 \\
\hline Highest $\mathrm{I}_{\text {geo }}$ & -0.02 & 0.02 & -0.58 & -0.52 & 0.46 & -0.39 & -0.53 & 0.16 & -0.44 & -0.86 \\
\hline Background & 11.2 & 0.097 & 12.7 & 61 & 22.6 & 29400 & 583 & 26.9 & 26.0 & 74.2 \\
\hline
\end{tabular}

Note: the background data are from the CEPA (1990). 
and suggesting that the elements except for Co, Mn and $\mathrm{Cu}$ might have single source.

\subsection{Evaluation of pollutions}

As mentioned above, a series of methods have been applied for the evaluation of elemental pollutions. In this study, three of them have been chosen for calculation.

The first one is the single pollution index $\left(\mathrm{P}_{\mathrm{i}}\right)$, which was defined by:

$$
\mathrm{P}_{\mathrm{i}}=\mathrm{C}_{\mathrm{M}} / \mathrm{C}_{\mathrm{S}} \text {, }
$$

where $C_{M}$ and $C_{S}$ are the concentration of sample and background, respectively. Previous studies revealed that the pollution degrees can be classified to be three according to the threshold values of $\mathrm{P}_{\mathrm{i}}$ : light $(<1)$, moderate (1-3) and significant (>3) (Liang et al., 2011). In this study, the national soil environmental background values of China (A-layer, Chinese Environmental Protection Administration [CEPA], 1990) have been chosen to be the background, and the calculated results of $P_{i}$ values are shown in Table 1. As can be seen from the table, the soil samples are moderately polluted by $\mathrm{As}, \mathrm{Cu}, \mathrm{Fe}, \mathrm{Ni}$ and $\mathrm{Pb}$ with $P_{i}$ values of them are higher than 1 , whereas others are light because their $\mathrm{P}_{\mathrm{i}}$ values are lower than 1 . Moreover, it is noticed that the mean concentrations of $\mathrm{Cd}$, Co, $\mathrm{Cr}$ and $\mathrm{Mn}$ are lower than the background. However, their highest concentrations are higher than their background values, which suggesting that the concentrations of them vary from area to area.

Another index, the geo-accumulation index $\left(\mathrm{I}_{\text {geo }}\right)$ has also been applied for the pollution assessment (Praveena et al., 2008). The calculation of $\mathrm{I}_{\text {geo }}$ is as follow:

$$
\mathrm{I}_{\text {geo }}=\log _{2}\left(\mathrm{C}_{\mathrm{M}} /\left(1.5 \times \mathrm{C}_{\mathrm{S}}\right)\right) \text {. }
$$

The classification of pollution degrees based on the $\mathrm{I}_{\text {geo }}$ values can be subdivided into five degrees: unpolluted $(<0)$, light $(0-1)$, moderate (1-3), heavy (3-5) and serious $(>5)$. The mean $\mathrm{I}_{\text {geo }}$ values of the samples show "unpolluted" characters for all of the elements $\left(\mathrm{I}_{\text {geo }}<0\right)$, whereas some of the elements $\left(\mathrm{Cd}, \mathrm{Cu}\right.$ and $\mathrm{Ni}$ ) have the highest $\mathrm{I}_{\text {geo }}$ values between 0 and 1 , implying that they have suffered light pollution for some of the locations.

Different with the $\mathrm{P}_{\mathrm{i}}$ and $\mathrm{I}_{\text {geo }}$, another index, the Nemerow composite index $\left(\mathrm{P}_{\mathrm{s}}\right)$ considers all of the elements rather than the single ones, the calculation of the $\mathrm{P}_{s}$ is as follow:

$$
\mathrm{P}_{\mathrm{s}}=\mathrm{SQRT}\left(\left(\mathrm{P}_{\mathrm{i}} \mathrm{m}^{2}+\mathrm{P}_{\mathrm{i}} \mathrm{x}^{2}\right) / 2\right),
$$

where $\mathrm{P}_{\mathrm{i}} \mathrm{m}$ and $\mathrm{P}_{\mathrm{i}} \mathrm{x}$ are the mean and maximum of $\mathrm{P}_{\mathrm{i}}$ values of all elements, respectively. Based on the $P_{s}$ values, the quality of soil can also be classified to be five grades: safety $(<0.7)$, precaution $(0.7-1.0)$, slightly polluted $(1-2)$, moderately polluted $(2-3)$ and seriously polluted $(>3)$ (Dai et al., 2008). In this study, the calculated $P_{s}$ values for all of the samples range from 0.93 to 1.66 (mean $=$
1.21 ), only four sample has $0.7 \leq \mathrm{P}_{\mathrm{s}}<1.0$, which means that most of soil samples in this study can be classified to be slightly polluted.

\subsection{Separation of pollution sources}

The relationships between elements can give information about their sources, because some of the elements with good correlation are always considered to have similar sources (Cobelo-García \& Prego, 2004), which can be obtained through correlation analysis. In this study, some of the elements show close positive relationships (correlation coefficients higher than the critical value $r_{a}=0.23$, $\mathrm{a}=0.05, \mathrm{n}=75$ ): e.g. Cd-Cu, Co-Fe and Co-Mn (Table 2). Such results suggest that their concentrations change simultaneously, and indicating that they might have been affected by similar factors or, have similar sources. However, some of the elements have negative correlations, e.g. the $\mathrm{As}$ and $\mathrm{Cu}$ show negative correlations with almost all of the other elements, implying that they might have different sources.

Cluster analysis comprises of a series of multivariate methods which are used to find true groups of data. In clustering, the objects are grouped such that similar objects fall into the same class. The method has long been used for environmental studies (Chen et al., 1997, 2005). In this study, the hierarchical R-mode cluster analysis has been applied to the data, and the "Ward" linkage and the "Pearson" distance have been chosen for calculation, and the results are shown in Figure 2 as a dendrogram. As can be seen from the figure, two main groups can be identified: As-Cu-Cd-Ni (Group 1) and Cr-Co-Fe-Mn-Pb-Zn (Group 2), which indicate that the elements in the similar group might have similar sources.

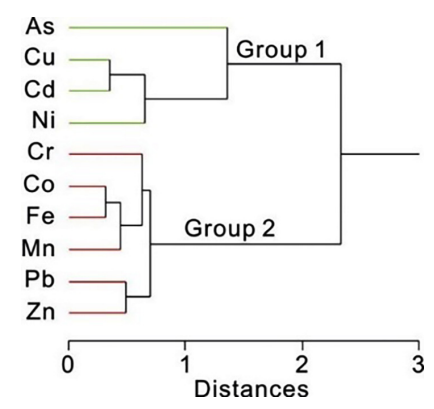

Figure 2. Dendrogram of R-mode cluster analysis

Factor analysis is a commonly used statistical method to classify, simplify and identify the most important variables in data sets through dimensionality reduction. During geochemical studies, factor analysis has long been used for tracing elemental sources (Lin, Teng, \& Chang, 2002; Grande, Borrego, \& Morales, 2010). In this study, based on the criteria of initial eigenvalue ( $>1$, Kaiser criterion) (Maiz, Arambarri, Garcia, \& Millan, 2000), three factors were obtained with total variance explanation of $69.8 \%$ (Table 3): the first one with strong positive loadings $(>0.75)$ of $\mathrm{Co}, \mathrm{Fe}$ and $\mathrm{Pb}$ and moderate positive loadings (0.50-0.75) of $\mathrm{Zn}, \mathrm{Mn}$ and $\mathrm{Cr}$, and it has $33.8 \%$ of the total 
Table 2. Results of correlation analysis $\left(n=75, a=0.05, r_{a}=0.227\right)$. Bold ones are those higher than the critical value

\begin{tabular}{|c|c|c|c|c|c|c|c|c|c|}
\hline & $\mathrm{As}$ & $\mathrm{Cd}$ & $\mathrm{Co}$ & $\mathrm{Cr}$ & $\mathrm{Cu}$ & $\mathrm{Fe}$ & $\mathrm{Mn}$ & $\mathrm{Ni}$ & $\mathrm{Pb}$ \\
\hline $\mathrm{Cd}$ & -0.090 & & & & & & & \\
\hline $\mathrm{Co}$ & -0.155 & 0.162 & & & & & & \\
\hline $\mathrm{Cr}$ & -0.227 & 0.116 & $\mathbf{0 . 4 2 1}$ & & & & & \\
\hline $\mathrm{Cu}$ & 0.085 & $\mathbf{0 . 6 5 4}$ & 0.051 & 0.120 & & & & \\
\hline $\mathrm{Fe}$ & -0.221 & -0.280 & $\mathbf{0 . 6 8 8}$ & $\mathbf{0 . 5 8 3}$ & -0.234 & & & \\
\hline $\mathrm{Mn}$ & -0.059 & -0.067 & $\mathbf{0 . 5 4 2}$ & $\mathbf{0 . 3 7 3}$ & -0.155 & $\mathbf{0 . 6 4 4}$ & & \\
\hline $\mathrm{Ni}$ & -0.202 & $\mathbf{0 . 5 7 3}$ & $\mathbf{0 . 2 6 0}$ & $\mathbf{0 . 3 7 2}$ & $\mathbf{0 . 2 7 4}$ & 0.207 & 0.168 & & \\
\hline $\mathrm{Pb}$ & -0.045 & -0.224 & $\mathbf{0 . 4 6 2}$ & $\mathbf{0 . 2 5 2}$ & -0.044 & $\mathbf{0 . 5 4 0}$ & $\mathbf{0 . 4 6 6}$ & -0.060 & \\
\hline $\mathrm{Zn}$ & -0.174 & 0.209 & $\mathbf{0 . 6 0 6}$ & $\mathbf{0 . 3 6 2}$ & 0.205 & $\mathbf{0 . 5 2 3}$ & $\mathbf{0 . 3 6 0}$ & $\mathbf{0 . 2 6 9}$ & $\mathbf{0 . 5 1 2}$ \\
\hline
\end{tabular}

variance explanation. The second one is characterized by strong positive loadings of $\mathrm{Cd}$ and $\mathrm{Cu}$, and moderate positive loading of $\mathrm{Ni}$, and it has $21.7 \%$ of the total variance explanation. Moreover, the third factor has $14.3 \%$ of the total variance explanation and has moderate positive loading of $\mathrm{Ni}$ and significant negative loading of As.

Previous studies revealed that four sources are responsible for the heavy metals (including arsenic) in the farmland soil, including the natural/geogenic processes (weathering of soil parental materials), the dustfall (mainly related to the coal combustion and traffic), agriculture (related to application of fertilizers and pesticides, and sewage irrigation) and mining activities (Huamain, Chunrong, Cong, \& Yongguan, 1999; Wang, 2019). In consideration with the natural condition of the study area, three sources can be considered to be responsible for the soil elements in this study: the geogenic source related to the formation of the soil (weathering), the agricultural activities (application of fertilizers and pesticides) and traffic related activities (vehicle exhaust emissions, releasing from the lubricant and wearing of tyres). Although Suzhou is a coal producing area, the coal combustion and coal related industry (coal chemical industry and coal electricity) is limited, and the sampling site is far away from the coal power plant, and therefore, the contribution of coal-related pollution to soil in this study may be limited.

Based on this consideration, the first factor can be explained to be the geogenic source, because the most abundant element Fe has the highest positive loadings in this factor relative to other two factors. Although some other sources can affect the Fe concentration in the soil, it is hard to exceed the background value $(29400 \mathrm{mg} / \mathrm{kg}$ ) except for the existence of iron ore.

Previous studies revealed that the application of superphosphate can increase the concentrations of $\mathrm{Cd}$, As and $\mathrm{Pb}$ in the soil (Wang, Li, Hao, \& Zhang, 2010), whereas the long-term use of pesticides can increase the $\mathrm{Cu}$ concentration in the soil (Wang, 2019). Therefore, the second factor can be explained to be the agricultural source because $\mathrm{Cd}$ and $\mathrm{Cu}$ have high positive loadings, and the loading of As is positive in this factor relative to other two factors.
Table 3. Results of factor analysis

\begin{tabular}{|l|c|c|c|}
\hline & Factor 1 & Factor 2 & Factor 3 \\
\hline $\mathrm{As}$ & -0.039 & 0.062 & -0.802 \\
\hline $\mathrm{Cd}$ & -0.081 & 0.913 & 0.163 \\
\hline $\mathrm{Co}$ & 0.807 & 0.167 & 0.159 \\
\hline $\mathrm{Cr}$ & 0.534 & 0.164 & 0.481 \\
\hline $\mathrm{Cu}$ & -0.005 & 0.856 & -0.198 \\
\hline $\mathrm{Fe}$ & 0.840 & -0.243 & 0.321 \\
\hline $\mathrm{Mn}$ & 0.740 & -0.122 & 0.122 \\
\hline $\mathrm{Ni}$ & 0.164 & 0.592 & 0.543 \\
\hline $\mathrm{Pb}$ & 0.780 & -0.147 & -0.215 \\
\hline $\mathrm{Zn}$ & 0.741 & 0.314 & 0.047 \\
\hline Eigen value & 3.38 & 2.17 & 1.43 \\
\hline Variance explained & $33.8 \%$ & $21.7 \%$ & $14.3 \%$ \\
\hline
\end{tabular}

As to the third factor, only $\mathrm{Ni}$ has moderate loading and then followed by $\mathrm{Cr}$. This factor might be explained to be the natural source (e.g. weathering of parental materials, especially the dark minerals, such as biotite), because most of the studies demonstrated that both $\mathrm{Cr}$ and $\mathrm{Ni}$ in soil are natural origin (Zheng et al., 2003; Huang, Xu, \& Zhang, 2007).

Moreover, previous studies revealed that $\mathrm{Zn}$ is one of the most abundant heavy metals released by wearing of tire and releasing from the lubricant, because $\mathrm{Zn}$ and $\mathrm{Co}$ are additives for tire manufacturing. Although $\mathrm{Pb}$ cannot be released by gasoline combustion with the use of unleaded gasoline, the previously accumulated $\mathrm{Pb}$ is still existed in the soil near the trafficway because of its immobility (Shao, Xiao, Wu, \& Tang, 2012). And therefore, the high loadings of $\mathrm{Zn}$, $\mathrm{Co}$ and $\mathrm{Pb}$ in the first factor might be an indication that the first factor is also related to traffic and they might be adsorbed by the Fe and Mn oxides or hydroxides. 


\subsection{Quantification of source contributions}

After the calculation of Unmix model, three sources responsible for the trace elemental concentrations in the soil samples have been identified (Table 4 and Figure 3) with Min Rsq $=0.99$ and Min Sig/Noise $=2.45$, higher than the criterion of the model (Min Rsq $>0.8$ and Min $\mathrm{Sig} /$ Noise $>2$ ), indicating that the analysis is efficient (Ai, Wang, \& Yang, 2014). Moreover, the correlations between the measured and predicted values are significant at $\mathrm{a}=0.05$ lever (range between 0.545 and 0.963 , higher than $r_{a}=0.227$ with $n=75$ ). Detailed information about each source are as follows:

The first source is characterized by highest As proportion (48.2\%) with moderate $\mathrm{Cu}(48.0 \%), \mathrm{Cd}(35.3 \%)$ and $\mathrm{Ni}(23.2 \%)$ relative to other sources, and this source can be explained to be the agricultural source, because $\mathrm{As}, \mathrm{Cu}$, and $\mathrm{Cd}$ are always used for fertilizers and pesticides.

The third factor is characterized by highest proportions of most of the elements, including the $\mathrm{Cd}(64.7 \%)$, $\mathrm{Co}(38.8 \%), \mathrm{Cr}(38.9 \%), \mathrm{Cu}(48.3 \%), \mathrm{Ni}(56.8 \%)$ and $\mathrm{Zn}(37.8 \%)$, and moderate $\mathrm{Fe}(34.3 \%), \mathrm{Mn}(34.9 \%)$ and $\mathrm{Pb}(33.7 \%)$ relative to other sources, and therefore, this source can be explained to be the geogenic source, because the soil itself is considered to be the main contributor for the elemental concentrations in it under the condition of no or light anthropogenic contributions, which has been demonstrated by the pollution assessment therein.

Comparatively, the second source is characterized by highest $\mathrm{Fe}$ (39.0\%), $\mathrm{Mn}(41.1 \%)$ and $\mathrm{Pb}(34.8 \%)$ proportions and moderate As (33.1\%), Co (35.4\%), Cr (34.2\%) and $\mathrm{Zn} \mathrm{(32.7 \% )} \mathrm{proportions} \mathrm{relative} \mathrm{to} \mathrm{other} \mathrm{sources.} \mathrm{In}$ consideration that the first and third sources are related to agriculture and geological condition, respectively, this source is therefore defined to be the traffic related source, which can also be supported by the medium proportions of Co and $\mathrm{Zn}$, the two elements always related to traffic (wearing of tire) (Shao et al., 2012).

The contributions of the three sources are shown in Figure 3. As can be seen from the figure, the contributions of the source 1 (agriculture related) range from $2.73 \%$ to $79.8 \%$ (mean is $33.2 \%$ ) for all of the samples, and the contributions of the source 2 (traffic related) is from $6.78 \%$ to $63.8 \%$ (mean is $33.3 \%$ ). Comparatively, the source 3 has

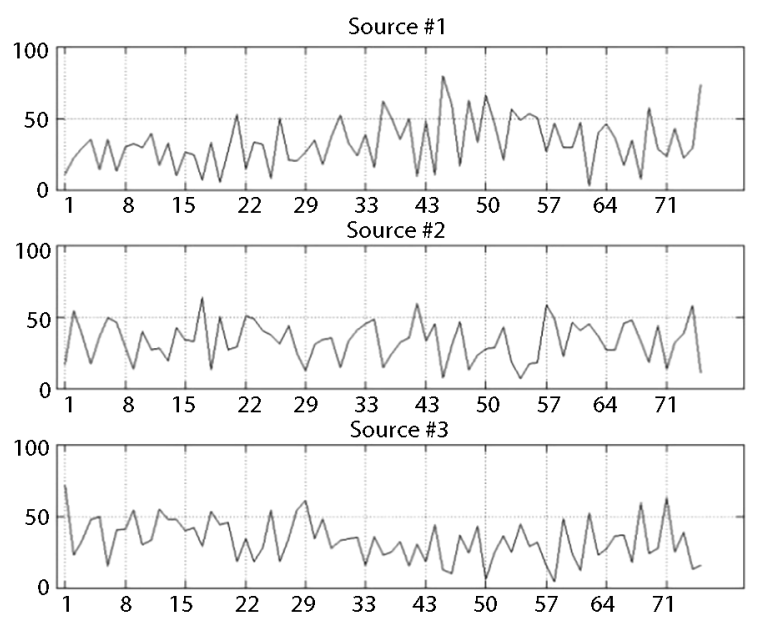

Figure 3. Variations of source contributions (\%) for each sample

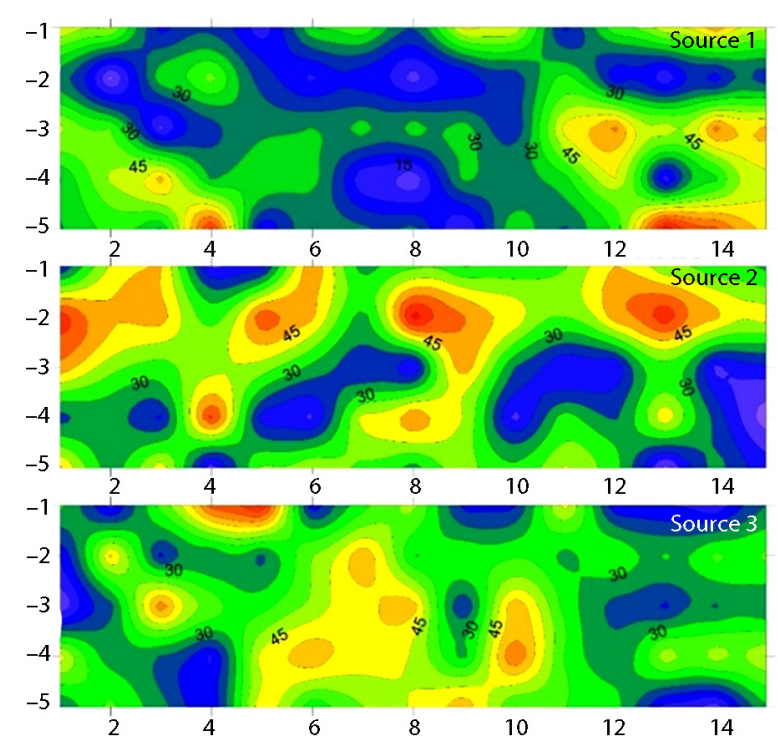

Figure 4. Spatial distributions of source contributions (\%)

Table 4. Source profiles $(\mathrm{mg} / \mathrm{kg})$ and proportions

\begin{tabular}{|c|c|c|c|c|c|c|c|}
\hline Species & Source 1 & Source 2 & Source 3 & Total & Proportion 1 & Proportion 2 & Proportion 3 \\
\hline $\mathrm{As}$ & 5.51 & 3.78 & 2.14 & 11.4 & $48.2 \%$ & $33.1 \%$ & $18.7 \%$ \\
\hline $\mathrm{Cd}$ & 0.035 & 0.000 & 0.063 & 0.098 & $35.3 \%$ & $0 \%$ & $64.7 \%$ \\
\hline $\mathrm{Co}$ & 2.86 & 3.93 & 4.31 & 11.1 & $25.8 \%$ & $35.4 \%$ & $38.8 \%$ \\
\hline $\mathrm{Cr}$ & 14.1 & 17.9 & 20.4 & 52.4 & $26.9 \%$ & $34.2 \%$ & $38.9 \%$ \\
\hline $\mathrm{Cu}$ & 14.4 & 1.13 & 14.5 & 30.0 & $48.0 \%$ & $3.80 \%$ & $48.3 \%$ \\
\hline $\mathrm{Fe}$ & 8000 & 11700 & 10300 & 30000 & $26.7 \%$ & $39.0 \%$ & $34.3 \%$ \\
\hline $\mathrm{Mn}$ & 104 & 178 & 151 & 433 & $24.0 \%$ & $41.1 \%$ & $34.9 \%$ \\
\hline $\mathrm{Ni}$ & 7.32 & 6.30 & 17.9 & 31.5 & $23.2 \%$ & $20.0 \%$ & $56.8 \%$ \\
\hline $\mathrm{Pb}$ & 8.60 & 9.47 & 9.18 & 27.3 & $31.6 \%$ & $34.8 \%$ & $33.7 \%$ \\
\hline $\mathrm{Zn}$ & 15.5 & 17.2 & 19.9 & 52.6 & $29.5 \%$ & $32.7 \%$ & $37.8 \%$ \\
\hline
\end{tabular}


contributions range from $4.55 \%$ to $71.9 \%$ (mean $=33.4 \%$ ). In a word, each source has $1 / 3$ contribution.

The spatial distributions of source contributions in Figure 4 can be identified that the areas with high contributions from the sources 2 are located in a line from the east to west, which is consistent with the direction of the trafficway and further supporting that the source 2 is a traffic related source. Comparatively, there is no significant law of the distributions of the source 1 and 3 contributions, which suggesting that the contributions of these two sources are inhomogeneous from area to area.

\section{Conclusions}

The following conclusions have been obtained:

(1) The elemental concentrations are $\mathrm{Fe}>\mathrm{Mn}>\mathrm{Zn}>$ $\mathrm{Cr}>\mathrm{Ni}>\mathrm{Cu}>\mathrm{Pb}>\mathrm{As}>\mathrm{Co}>\mathrm{Cd}$. They have low-medium coefficients of variation (0.028-0.281).

(2) The single pollution, geo-accumulation and the Nemerow composite indexes suggest that the soils in this study are slightly polluted.

(3) Statistical analyses indicate that three sources are responsible for the soil elemental concentrations, the geogenic, agricultural and traffic related sources, and their mean contributions calculated by the Unmix model are $33.4 \%, 33.2 \%$ and $33.3 \%$, respectively.

\section{Acknowledgements}

Thanks very much to Han Sun, Zixiang Zhao, Yu Li and Xiaojun Gao for their help in sampling and analyses of metal concentrations. This work was financially supported by the Academic Funding for Top-talents in Disciplines of Universities in Anhui Province (gxbjZD48).

\section{References}

Ai, J. C., Wang, N., \& Yang, J. (2014). Source apportionment of soil heavy metals in Jiapigou goldmine based on the UNMIX model. Environmental Science, 35(9), 3530-3536.

Alsbou, E. M. E., \& Al-Khashman, O. A. (2018). Heavy metal concentrations in roadside soil and street dust from Petra region, Jordan. Environmental Monitoring and Assessment, 190(1), 48. https://doi.org/10.1007/s10661-017-6409-1

Antisari, L. V., Orsini, F., Marchetti, L., Vianello, G., \& Gianquinto, G. (2015). Heavy metal accumulation in vegetables grown in urban gardens. Agronomy for Sustainable Development, 35(3), 1139-1147. https://doi.org/10.1007/s13593-015-0308-Z

Arojojoye, O. A., Oyagbemi, A. A., \& Afolabi, J. M. (2018). Toxicological assessment of heavy metal bioaccumulation and oxidative stress biomarkers in Clarias gariepinus from Igbokoda River of South Western Nigeria. Bulletin of Environmental Contamination and Toxicology, 100, 765-771. https://doi.org/10.1007/s00128-018-2341-5

Carslaw, D. C. (2005). Evidence of an increasing $\mathrm{NO}_{2} / \mathrm{NO}_{\mathrm{x}}$ emissions ratio from road traffic emissions. Atmospheric Environment, 39(26), 4793-4802.

https://doi.org/10.1016/j.atmosenv.2005.06.023

CEPA. (1990). Elemental background values of soils in China. Beijing: Environmental Science Press of China.
Chen, T. B., Wong, J. W. C., Zhou, H. Y., \& Wong, M. H. (1997). Assessment of trace metal distribution and contamination in surface soils of Hong Kong. Environmental Pollution, 96(1), 61-68. https://doi.org/10.1016/S0269-7491(97)00003-1

Chen, T. B., Zheng, Y. M., Lei, M., Huang, Z. C., Wu, H. T., Chen, H., Fan, K. K., Yu, K., Wu, X., \& Tian, Q. Z. (2005). Assessment of heavy metal pollution in surface soils of urban parks in Beijing, China. Chemosphere, 60(4), 542-551. https://doi.org/10.1016/j.chemosphere.2004.12.072

Chon, H. T., Kim, K. W., \& Kim, J. Y. (1995). Metal contamination of soils and dusts in Seoul metropolitan city, Korea. Environmental Geochemistry and Health, 17(3), 139-146. https://doi.org/10.1007/BF00126082

Cobelo-García, A., \& Prego, R. (2004). Influence of point sources on trace metal contamination and distribution in a semienclosed industrial embayment: the Ferrol Ria (NW Spain). Estuarine, Coastal and Shelf Science, 60(4), 695-703. https://doi.org/10.1016/j.ecss.2004.03.008

Dai, J., Li, S., Zhang, Y., Wang, R., \& Yu, Y. (2008). Distributions, sources and risk assessment of polycyclic aromatic hydrocarbons (PAHs) in topsoil at Ji'nan city, China. Environmental Monitoring and Assessment, 147(1-3), 317-326. https://doi.org/10.1007/s10661-007-0123-3

De Silva, S., Ball, A. S., Huynh, T., \& Reichman, S. M. (2016). Metal accumulation in roadside soil in Melbourne, Australia: effect of road age, traffic density and vehicular speed. Environmental Pollution, 208, 102-109. https://doi.org/10.1016/j.envpol.2015.09.032

Duruibe, J. O., Ogwuegbu, M. O. C., \& Egwurugwu, J. N. (2007). Heavy metal pollution and human biotoxic effects. International Journal of Physical Sciences, 2(5), 112-118.

Grande, J. A., Borrego, J., \& Morales, J. A. (2000). A study of heavy metal pollution in the Tinto-Odiel estuary in southwestern Spain using factor analysis. Environmental Geology, 39(10), 1095-1101. https://doi.org/10.1007/s002549900080

Guo, G. H., Chen, T. B., Song, B., Yang, J., Huang, Z. C., Lei, M., \& Chen, Y. C. (2007). Emissions of heavy metals from road traffic and effect of emitted lead on land contamination in China: a primary study. Geographical Research, 26(5), 922930.

Han, Y., Cao, J., \& Posmentier, E. S. (2006). Multivariate analysis of heavy metal contamination in urban dusts of Xi'an, Central China. Science of the Total Environment, 355(1-3), 176186. https://doi.org/10.1016/j.scitotenv.2005.02.026

Harrison, R. M., Tilling, R., Romero, M. S. C., Harrad, S., \& Jarvis, K. (2003). A study of trace metals and polycyclic aromatic hydrocarbons in the roadside environment. Atmospheric Environment, 37(17), 2391-2402. https://doi.org/10.1016/S1352-2310(03)00122-5

Huamain, C., Chunrong, Z., Cong, T. U., \& Yongguan, Z. (1999). Heavy metal pollution in soils in China: status and countermeasures. Ambio, 28(2), 130-134.

Huang, Y., Li, T., Wu, C., He, Z., Japenga, J., Deng, M., \& Yang, X. (2015). An integrated approach to assess heavy metal source apportionment in peri-urban agricultural soils. Journal of Hazardous Materials, 299, 540-549. https://doi.org/10.1016/j.jhazmat.2015.07.041

Huang, Z. P., Xu, B., \& Zhang, K. Q. (2007). Spatial variability and accumulation of $\mathrm{Cr}$ and $\mathrm{Ni}$ in farmland soil of swine wastewater applied. Ecology and Environment, 16(6), 16941699.

Islam, M. S., Ahmed, M. K., Raknuzzaman, M., Habibullah-AlMamun, M., \& Islam, M. K. (2015). Heavy metal pollution in surface water and sediment: a preliminary assessment of an 
urban river in a developing country. Ecological Indicators, 48, 282-291. https://doi.org/10.1016/j.ecolind.2014.08.016

Ji, C., Cao, L., \& Li, F. (2015). Toxicological evaluation of two pedigrees of clam Ruditapes philippinarum as bioindicators of heavy metal contaminants using metabolomics. Environmental Toxicology and Pharmacology, 39(2), 545-554. https://doi.org/10.1016/j.etap.2015.01.004

Lang, Y. H., \& Yang, W. (2014). Source apportionment of PAHs using Unmix model for Yantai costal surface sediments, China. Bulletin of Environmental Contamination and Toxicology, 92(1), 30-35. https://doi.org/10.1007/s00128-013-1164-7

Lewis, C. W., Norris, G. A., Conner, T. L., \& Henry, R. C. (2003). Source apportionment of Phoenix PM2. 5 aerosol with the Unmix receptor model. Journal of the Air \& Waste Management Association, 53(3), 325-338.

https://doi.org/10.1080/10473289.2003.10466155

Li, R., Zhao, W., Li, Y., Wang, W., \& Zhu, X. (2015). Heavy metal removal and speciation transformation through the calcination treatment of phosphorus-enriched sewage sludge ash. Journal of Hazardous Materials, 283, 423-431. https://doi.org/10.1016/j.jhazmat.2014.09.052

Liang, J., Chen, C., Song, X., Han, Y., \& Liang, Z. (2011). Assessment of heavy metal pollution in soil and plants from Dunhua sewage irrigation area. International Journal of Electrochemical Science, 6(11), 5314-5324.

Lin, Y. P., Teng, T. P., \& Chang, T. K. (2002). Multivariate analysis of soil heavy metal pollution and landscape pattern in Changhua county in Taiwan. Landscape and Urban planning, 62(1), 19-35. https://doi.org/10.1016/S0169-2046(02)00094-4

Linde, M., Bengtsson, H., \& Öborn, I. (2001). Concentrations and pools of heavy metals in urban soils in Stockholm, Sweden. Water, Air and Soil Pollution: Focus, 1(3-4), 83-101. https://doi.org/10.1023/A:1017599920280

Maiz, I., Arambarri, I., Garcia, R., \& Millan, E. (2000). Evaluation of heavy metal availability in polluted soils by two sequential extraction procedures using factor analysis. Environmental Pollution, 110(1), 3-9. https://doi.org/10.1016/S0269-7491(99)00287-0

Mehdi, M. R., Kim, M., Seong, J. C., \& Arsalan, M. H. (2011). Spatio-temporal patterns of road traffic noise pollution in Karachi, Pakistan. Environment International, 37(1), 97-104. https://doi.org/10.1016/j.envint.2010.08.003

Mei, J., Li, Z., Sun, L., Gui, H., \& Wang, X. (2011). Assessment of heavy metals in the urban river sediments in Suzhou City, northern Anhui Province, China. Procedia Environmental Sciences, 10, 2547-2553.

https://doi.org/10.1016/j.proenv.2011.09.396

MOT. (2017). Statistical bulletin on transportation industry development in 2017, China. Logistics and Procurement in China, 11, 51-55.

Praveena, S. M., Ahmed, A., Radojevic, M., Abdullah, M. H., \& Aris, A. Z. (2008). Heavy metals in mangrove surface sedi- ment of Mengkabong lagoon, Sabah: multivariate and geoaccumulation index approaches. International Journal of Environmental Research, 2(2), 139-148.

Radu, T., \& Diamond, D. (2009). Comparison of soil pollution concentrations determined using AAS and portable XRF techniques. Journal of Hazardous Materials, 171(1-3), 11681171. https://doi.org/10.1016/j.jhazmat.2009.06.062

Sarkar, D., Datta, R., \& Hannigan, R. (2011). Concepts and applications in environmental geochemistry (Vol. 5). Elsevier.

Shao, L., Xiao, H. Y., Wu, D. S., \& Tang, C. G. (2012). Review on research on traffic-related heavy metals pollution. Earth and Environment, 40(3), 445-459.

Sun, H., Zhu, L., \& Zhou, D. (2018). POLSOIL: research on soil pollution in China. Environmental Science and Pollution Research, 25, 1-3.

Sun, L., \& Feng, S. (2019). Heavy metals in the surface soil around a coalmine: pollution assessment and source identification. Polish Journal of Environmental Studies, 28(4), 27172724. https://doi.org/10.15244/pjoes/94052

Sun, L., Liu, X., \& Cheng, C. (2016a). Quality evaluation of water from subsidence area and controlling factor analysis: Zhuxianzhuang case study. Nature Environment and Pollution Technology, 15(3), 1035-1040.

Sun, L., Peng, W., \& Cheng, C. (2016b). Source estimating of heavy metals in shallow groundwater based on UNMIX Model: a case study. Indian Journal of Geo-Marine Sciences, 45(6), 756-762.

Sun, L., Xie, Z., \& Guo, C. (2014). Environmental baseline of iron and aluminum in surface soil: a case study based on statistical and spatial analyses. International Journal of Earth Sciences \& Engineering, 7(5), 1937-1942.

Tóth, G., Hermann, T., Da Silva, M. R., \& Montanarella, L. (2016). Heavy metals in agricultural soils of the European Union with implications for food safety. Environment International, 88, 299-309. https://doi.org/10.1016/j.envint.2015.12.017

Wang, G. L., Li, L. K., Hao, M. D., \& Zhang, M. (2010). Effects of long-term fertilization on heavy-metal contents of soil and environmental quality evaluation. Journal of Soil and Water Conservation, 24(3), 60-63.

Wang, N. (2019). Study and analysis of sources of heavy metal pollution in farmland soil. China Metal Bulletin, 1, 289-290.

Zechmeister, H. G., Hohenwallner, D., Riss, A., \& Hanus-Illnar, A. (2005). Estimation of element deposition derived from road traffic sources by using mosses. Environmental Pollution, 138(2), 238-249. https://doi.org/10.1016/j.envpol.2005.04.005

Zheng, Y. M., Chen, H., Chen, T. B., Zheng, G. D., Wu, H. T., \& Zhou, J. L. (2003). Spatial distribution pattern of $\mathrm{Cr}$ and $\mathrm{Ni}$ in soils of Beijing. Quaternary Sciences, 23(4), 436-445.

Zupančič, N. (1999). Lead contamination in the roadside soils of Slovenia. Environmental Geochemistry and Health, 21(1), 37-50. https://doi.org/10.1023/A:1006539626650 